\title{
Recommended Alternative for Interim Stabilization of Tank 241-C-103
}

Prepared for the U.S. Department of Energy Office of Environmental Restoration and Waste Management

\section{(28) Westinghouse Hanford Company Richland, Washington}

Hanford Operations and Engineering Contractor for the

U.S. Department of Energy under Contract DE-AC06-87RL10930 
LEGAL DISCLAIMER

This report was prepared as an account of work sponsored by an agency of the United States Government. Neither the United States Government nor any agency thereof, nor any of their employees, nor any of their contractors, subcontractors or their employees, makes any warranty, express or implied, or assumes any legal liability or responsibility for the accuracy, completeness, or any third party's use or the results of such use of any information, apparatus, product, or process disclosed, or represents that its use would not infringe privately owned rights. Reference herein to any specific commercial product, process, or service by trade name, trademark, manufacturer, or otherwise, does not necessarily constitute or imply its endorsement, recommendation, or favoring by the United States Government or any agency thereof or its contractors or subcontractors. The views and opinions of authors expressed herein do not necesserily state or reflect those of the United States Government or any agency thereof.

This report has been reproduced from the best available copy. Available in paper copy and microfiche.

Available to the U.S. Department of Energy

and its contrectors from

Office of Scientific and Technical Information

P.O. Box 62

Oak Ridge, TN 37831

(615) 576-8401

Available to the public from the U.S. Department of Commerce National Technical Information Service

5285 Port Royal Road

Springfield, VA 22161

(703) $487-4650$

Printed in the United States of Americs

DISCLM-1.CHP (1-91) 


\section{DISCLAIMER}

Portions of this document may be illegible in electronic image products. Images are produced from the best available original document. 


\title{
Recommended Alternative for Interim Stabilization of Tank 241-C-103
}

\author{
G. T. Dukelow \\ D. A. Turner
}

Westinghouse Hanford Company

J. M. Grigsby

G \& P Consulting, Inc.

Date Published

April 1995

Prepared for the U.S. Department of Energy Office of Environmental Restoration and Waste Management

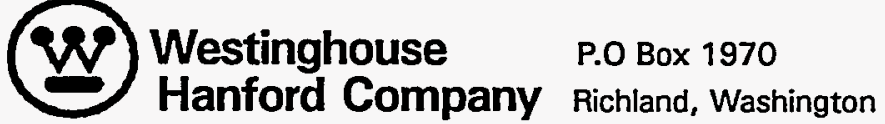

Hanford Operations and Engineering Contractor for the

U.S. Department of Energy under Contract DE-AC06-87RL10930

Approved for Public Release 


\section{RELEASE AUTHORIZATION}

Document Number: $\quad$ WHC-EP-0862

Document Title: $\quad$ Recommended ATternative for Interim Stabilization of Tank 241-C-103

Release Date: $\quad 4 / 27 / 95$

This document was reviewed following the procedures described in WHC-CM-3-4 and is:

APPROVED FOR PUBLIC RELEASE

WHC Information Release Administration Specialist:

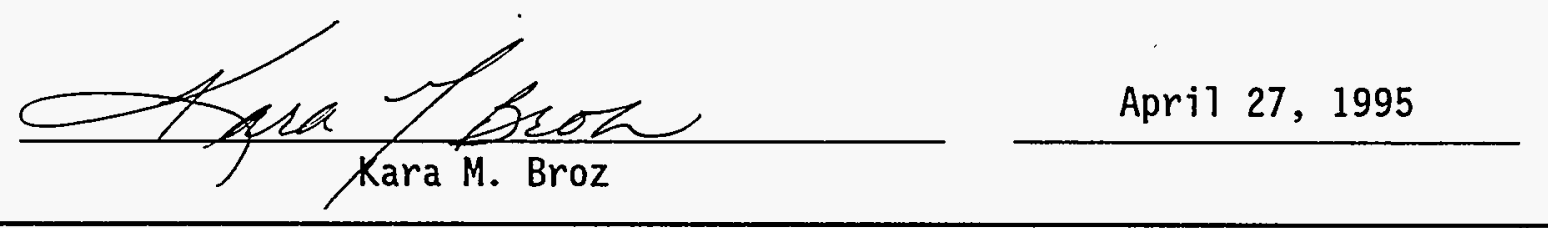




\section{CONTENTS}

1.0 EVALUATION OF ALTERNATIVES $\ldots \ldots \ldots \ldots \ldots \ldots \ldots \ldots \ldots \ldots \ldots$ 1.1 SUMMARY AND CONCLUSIONS $\ldots \ldots \ldots \ldots \ldots \ldots \ldots \ldots \ldots$

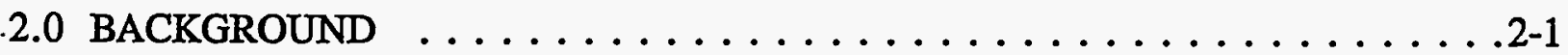

2.1 SOLVENT FIRE HAZARD $\ldots \ldots \ldots \ldots \ldots \ldots \ldots \ldots \ldots \ldots \ldots \ldots \ldots \ldots .2-1$

2.2 TOXIC VAPOR HAZARD $\ldots \ldots \ldots \ldots \ldots \ldots \ldots \ldots \ldots .2-2$

2.3 SOIL CONTAMINATION FROM TANK LEAKS $\ldots \ldots \ldots \ldots \ldots . . .2-2$

3.0 IDENTIFICATION OF ALTERNATIVES $\ldots \ldots \ldots \ldots \ldots \ldots \ldots \ldots$. . . . . . .

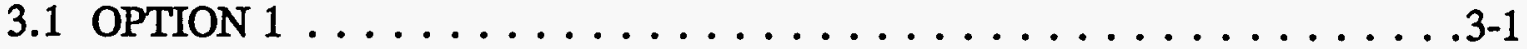

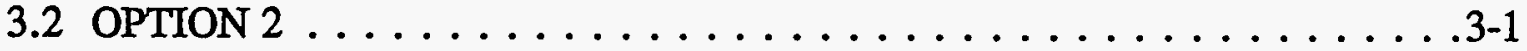

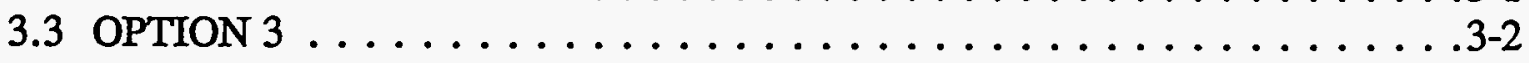

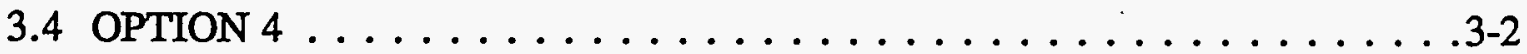

4.0 CRITERIA AND ASSUMPTIONS $\ldots \ldots \ldots \ldots \ldots \ldots \ldots \ldots . \ldots . \ldots .1$

4.1 PUBLIC HEALTH AND SAFETY . . . . . . . . . . . . . . 4-1

4.2 OCCUPATIONAL HEALTH AND SAFETY (ALARA) . . . . . . . 4-1

4.3 ENVIRONMENTAL COMPLIANCE $\ldots \ldots \ldots \ldots \ldots \ldots \ldots \ldots .1$

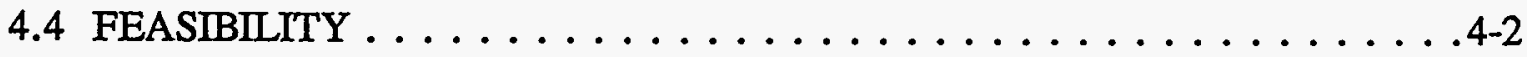

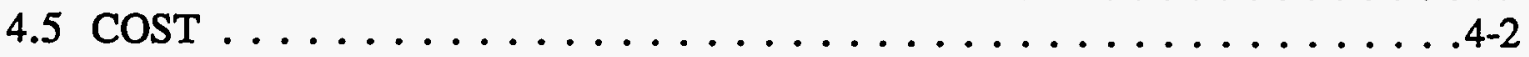

5.0 COMPARISON OF ALTERNATIVES AND SELECTION OF

RECOMMENDED OPTION . . . . . . . . . . . . . . . .5-1

5.1 PUBLIC HEALTH AND SAFETY $\ldots \ldots \ldots \ldots \ldots \ldots \ldots \ldots$. $\ldots \ldots$

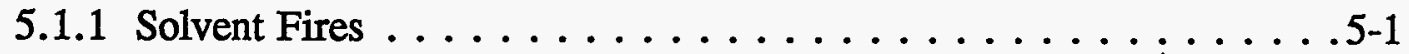

5.1 .2 Waste Transfer Accidents . . . . . . . . . . . . . 5-2

5.2 OCCUPATIONAL HEALTH AND SAFETY $\ldots \ldots \ldots \ldots \ldots \ldots .5-2$

5.2 .1 Radiation Exposure . . . . . . . . . . . . . . 5-2

5.2 .2 Toxic Gas Exposures . . . . . . . . . . . . . . 5-4

5.2 .3 Industrial Safety . . . . . . . . . . . . . . 5-4

5.3 ENVIRONMENTAL COMPLIANCE $\ldots \ldots \ldots \ldots \ldots \ldots \ldots$

5.3.1 Administrative Impacts . . . . . . . . . . . . . . 5-5

5.3 .2 Technical Impacts . . . . . . . . . . . . . . . . 5-5

5.3.3 Regulatory/Tri-Party Agreement Impacts . . . . . . . . . . 5-6

5.4 ENGINEERING FEASIBIITY $\ldots \ldots \ldots \ldots \ldots \ldots \ldots \ldots \ldots$

5.4 .1 Operability . . . . . . . . . . . . . . . .

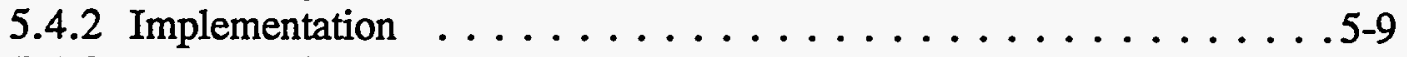

5.4.3 Decontamination and Decommissioning . . . . . . . . 5-10

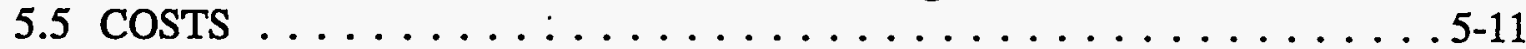

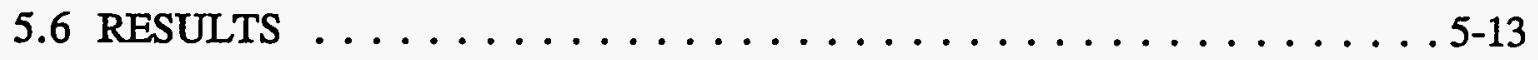

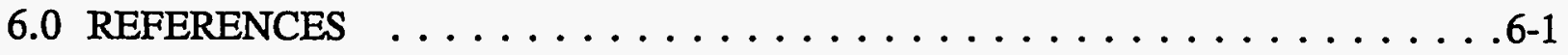


WHC-EP-0862

\section{LIST OF FIGURES}

5-1 Radiological Risk to Maximumally Exposed Onsite Receptor . . . . . . . . . . . . 5-3

\section{LIST OF TABLES}

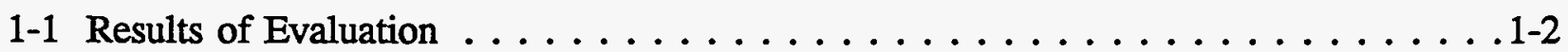

5-1 TPA Milestones for Interim Stabilization of Single-Shell Tanks . . . . . . . . . 5-7 


\section{LIST OF TERMS}

DCRT

DST

Ecology

EPA

NPH

PUREX

RAG

RCRA

SST

TBP double contained receiver tank

Double-Shell Tank

Washington Department of Ecology

Environmental Protection Agency

normal paraffin hydrocarbons

Plutonium Uranium Extraction

risk acceptance guidelines

Resource, Conservation and Recovery Act

single-shell tank

tributyl phosphate 
WHC-EP-0862

This page intentionally left blank. 


\subsection{EVALUATION OF ALTERNATIVES}

\subsection{SUMMARY AND CONCLUSIONS}

The waste in tank 241-C-103 poses several health and safety risks and potential soil contamination caused by tank leaks. To minimize the risk of contaminating the soil beneath the tank, the pumpable waste liquids are planned to be removed by salt well pumping. In addition to aqueous liquids, this tank is unique because it also contains a layer of degraded PUREX solvent floating on the aqueous liquid. The following three options for removing and storing this separable phase organic solvent have been proposed and studied:

- $\quad$ transferring the organic solvent and pumpable aqueous liquids using existing salt well pumping equipment and procedures to a double-shell tank (DST) for storage.

- removing most of the organic solvent using a skimmer pump, then salt well pumping the remaining pumpable liquids" to a different DST for storage.

- removing most of the organic solvent to an aboveground storage tank for eventual treatment or offsite transfer, and then salt well pumping the remaining pumpable liquids* to a DST for interim storage.

As a result of evaluating these three options and a no pumping option, the recommended action is to transfer both the organic solvent and pumpable aqueous liquid to a DST for storage using existing salt well pumping equipment.

The evaluation considers the following criteria: public health and safety, worker safety, environmental compliance, engineering feasibility, and cost. The options compared these factors (see Table 1-1). The evaluation rated each option on a scale of -3 to +3 against each weighted criterion. The option with the highest sum of ratings is the preferred option. Two key areas drove the selection of the recommended approach: the minimization of potential soil contamination from tank leaks caused the (interim stabilization by salt well pumping) options to be rated more highly than the no pumping option; and cost and implementation factors caused the transfer and storage to DST using existing tank farm salt well pumping equipment option to rate higher than the skimming options. Other factors have only a second order effect on the selection process. Evaluation results are described in this report.

"mostly aqueous liquids with small amount of organic solvent 
Table 1-1. Results of Evaluation.

\begin{tabular}{|c|c|c|c|c|}
\hline H. & & Rating & Hons gratuated & 3 \\
\hline i: & t: & 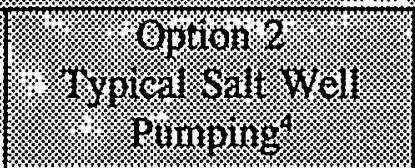 & 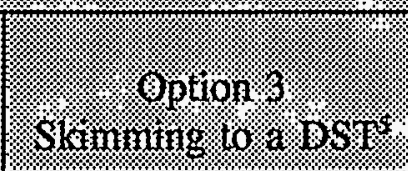 & 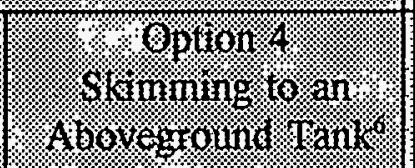 \\
\hline $\begin{array}{l}\text { A. Public safety (3) } \\
\text { 1. Solvent fire risk } \\
\text { 2. Waste transfer risk }\end{array}$ & $\begin{array}{ll}1 . & 0 \\
2 . & 0 \\
\text { avg } & 0 \\
\text { result } & 0 \times 3=0\end{array}$ & $\begin{array}{lc}1 . & 0 \\
2 . & -1 \\
\text { avg } & -0.5 \\
\text { result } & -0.5 \times 3=-1.5\end{array}$ & $\begin{array}{lc}1 . & 0 \\
2 . & -1 \\
\text { avg } & -0.5 \\
\text { result } & -0.5 \times 3=-1.5\end{array}$ & $\begin{array}{lc}1 . & 0 \\
2 . & -1 \\
\text { avg } & -0.5 \\
\text { result } & -0.5 \times 3=-1.5\end{array}$ \\
\hline $\begin{array}{l}\text { B. Worker safety (3) } \\
\text { 1. Radiation protection } \\
\text { 2. Toxic gases } \\
\text { 3. Industrial safety }\end{array}$ & $\begin{array}{lr}1 . & 1 \\
2 . & 0 \\
3 . & 1 \\
\text { avg } & 0.7 \\
\text { result } & 0.7 \times 3=2\end{array}$ & $\begin{array}{ll}1 . & 0 \\
2 . & 0 \\
3 . & 0 \\
\text { avg } & 0 \\
\text { result } & 0 \times 3=0\end{array}$ & $\begin{array}{lc}1 . & -1 \\
2 . & 0 \\
3 . & 0 \\
\text { avg } & -0.3 \\
\text { result } & -0.3 \times 3=-1\end{array}$ & $\left|\begin{array}{lc}1 . & -2 \\
2 . & 0 \\
3 . & -1 \\
\text { avg } & -1.0 \\
\text { result } & -1.0 \times 3=-3.0\end{array}\right|$ \\
\hline $\begin{array}{l}\text { C. Environmental } \\
\text { compliance (2) } \\
\text { 1. Administrative } \\
\text { 2. Soil column contamination } \\
\text { 3. Tri-Party Agreement } \\
\text { considerations }\end{array}$ & $\begin{array}{lc}1 . & 1 \\
2 . & -1 \\
3 . & -3 \\
\text { avg } & -1.0 \\
\text { result } & -1.0 \times 2=-2.0\end{array}$ & $\begin{array}{ll}1 . & 0 \\
2 . & 1 \\
3 . & 3 \\
\text { avg } & 1.3 \\
\text { result } & 1.3 \times 2=2.7\end{array}$ & $\begin{array}{ll}1 . & 0 \\
2 . & 1 \\
3 . & 2 \\
\text { avg } & 1.0 \\
\text { result } & 1.0 \times 2=2.0\end{array}$ & $\begin{array}{lc}1 . & 0 \\
2 . & 1 \\
3 . & 2 \\
\text { avg } & 1.0 \\
\text { result } & 1.0 \times 2=2.0\end{array}$ \\
\hline
\end{tabular}


Table 1-1. Results of Evaluation.

\begin{tabular}{|c|c|c|c|c|}
\hline la & (5) & 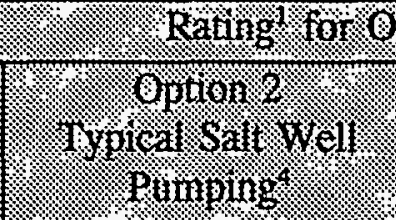 & Wons qutiat & is: \\
\hline $\begin{array}{l}\text { D. Feasibility (1) } \\
\text { 1. Operability } \\
\text { 2. Implementation } \\
\text { 3. Decontamination and } \\
\text { decommissioning (waste } \\
\text { handling) }\end{array}$ & $\begin{array}{lc}1 . & 1 \\
2 . & 1 \\
3 . & -1 \\
\text { avg } & 0.3 \\
\text { result } & 0.3 \times 1=0.3\end{array}$ & $\begin{array}{lc}1 . & 0 \\
2 . & 0 \\
3 . & -1 \\
& \\
\text { avg } & 0.3 \\
\text { result } & 0.3 \times 1=0.3\end{array}$ & $\begin{array}{lc}1 . & 0 \\
2 . & -1 \\
3 . & -1 \\
& \\
\text { avg } & 0.7 \\
\text { result } & 0.7 \times 1=0.7\end{array}$ & $\begin{array}{lc}1 . & 0 \\
2 . & -2 \\
3 . & 1 \\
\text { avg } & 0.3 \\
\text { result } & -0.3 \times 1=-0.3\end{array} \mid$ \\
\hline $\begin{array}{l}\text { E. Cost (2) } \\
\text { 1. Implementation } \\
\text { 2. Life-cycle } \\
\text { 3. Pre-treatment/disposal/site } \\
\text { cleanup }\end{array}$ & $\begin{array}{lc}1 . & 1 \\
2 . & -1 \\
3 . & -2 \\
\text { avg } & -0.7 \\
\text { result } & -0.7 \times 2=-1.3\end{array}$ & $\begin{array}{ll}1 . & 0 \\
2 . & 0 \\
3 . & 0 \\
\text { avg } & 0 \\
\text { result } & 0 \times 2=0\end{array}$ & $\begin{array}{lc}1 . & -1 \\
2 . & 0 \\
& -1 \\
\text { avg } & -0.7 \\
\text { result }-0.7 \times 2=-1.3\end{array}$ & $\begin{array}{lc}1 . & -2 \\
2 . & -1 \\
3 . & 0 \\
\text { avg } & -1.3 \\
\text { result } & -1.3 \times 2=-2.7\end{array}$ \\
\hline Total rating & -1.0 & 0.9 & -1.8 & -4.5 \\
\hline \multicolumn{5}{|c|}{$\begin{array}{l}\text { Notes: } \\
\text { 'A rating is assigned based on the option's relative benefit or detriment against each factor. The rating scale ranges from }-3 \text { to }+3 \text {. A }-3 \text { signifies a } \\
\text { major detriment, } 0 \text { is neutral, and }+3 \text { signifies a major benefit. Numbers in between signify less significant benefit and detriment ratings. } \\
\text { 2The evaluation criteria are weighted to better reflect the importance of some criteria over others. } \\
{ }^{3} \text { No action. (continued interim storage) } \\
{ }^{4} \text { Salt well pump solvent and aqueous to a double-shell tank using existing equipment and procedures. } \\
{ }^{5} \text { Skim solvent to a double-shell tank, salt well pump aqueous to another double-shell tank. } \\
{ }^{6} \text { Skim solvent to an aboveground tank, salt well pump aqueous to a double-shell tank. }\end{array}$} \\
\hline
\end{tabular}


WHC-EP-0862

This page intentionally left blank. 


\subsection{BACKGROUND}

Tank 241-C-103 contains approximately 26,000 gallons of sludge, 133,000 gallons of aqueous supernate, and approximately 4,000 to 5,500 gallons of degraded PUREX solvent (a mixture of normal paraffin hydrocarbons and tributyl phosphate) floating on the top of the aqueous supernate. This waste poses several safety, health and environmental hazards which have been studied extensively over the last several years. The most notable hazards include the following:

- the organic solvent poses a solvent pool fire accident risk which could lead to the release of radioactive and toxic combustion products and entrained waste

- chemical concentrations in the tank headspace are high enough to pose an exposure hazard to tank farm workers caused by the venting of headspace gases and vapors, most notably ammonia and organic compounds (acetonitrile, propane nitrile and tributyl phosphate)

- the drainable liquid (approximately 133,000 gallons) stored in this tank poses a contamination risk to the soil beneath the tank if a leak develops.

Removing the organic solvent and the drainable aqueous liquid has been proposed as a solution (or partial solution) to these hazards. However, additional study has indicated that removing the drainable liquids is not expected to significantly impact the risk from solvent fires or toxic gas exposures. Pumping tank liquids is expected only to significantly impact the risk of contaminating the soil column because of tank leaks.

Several options exist for removing and storing the liquids. One option would remove the majority of the organic solvent to an aboveground storage tank, then salt well pump the remaining organic solvent and drainable aqueous liquids to a DST following typical interim stabilization methods. A second.option would transfer the organic solvent with the aqueous liquid to a DST for storage. It is anticipated that either option will leave some amount of organic solvent and aqueous waste in tank $241-\mathrm{C}-103$ along with the waste sludge.

The effect on the three key hazards of removing tank liquids is summarized below and discussed in Section 5.0.

\subsection{SOLVENT FIRE HAZARD}

The safety analysis of the proposed pumping options indicates that the risk posed by solvent fires is low and well within risk acceptance guidelines for all options. This is primarily because the amount of solvent that can be burned is very small due to limited oxygen being available in the tank headspace. A solvent fire would consume only a small amount ( 60 kilograms or 70 liters) of the available solvent before being extinguished by a low 
concentration of oxygen. Solvent fire risk would be affected only if the removal process could be demonstrated to leave significantly less than 70 liters of solvent behind in tank 241-C-103. None of the liquid removal options considered is expected to have a high enough solvent removal efficiency to significantly impact the already low solvent fire risk.

\subsection{TOXIC VAPOR HAZARD}

Potentially toxic gases and vapors such as ammonia, nitrous oxide, acetonitrile, propane nitrile, and tributyl phosphate are being produced in the waste as a result of evaporation of solvent, radiolysis, and chemical reactions, which are occurring within the organic solvent, the aqueous liquids, and the waste sludges.

The concentration of toxic vapors is not expected to be reduced significantly by either removal option. Ammonia is likely to be generated in the aqueous liquids. Waste sludges tend to retain significant amounts of interstitial liquid after salt well pumping so it is anticipated that a significant amount of (non-pumpable) aqueous liquid will remain. Therefore, it is unlikely that ammonia generation rates will be reduced enough that headspace concentrations will no longer be a concern. While the majority of the solvent is expected to be removed by all of the pumping options, it is anticipated that the amount of remaining solvent will be sufficient to maintain the headspace at or near saturated conditions, and thus the headspace concentrations resulting from the evaporation of organic solvent are not expected to be reduced significantly. Mitigation of the toxic vapors is more effectively accomplished by other options including the vapor mixing system that is planned to be implemented on tank 241-C-103 in the near future.

The vapor mixing system involves installing a fresh air blower, the exhaust of which draws a small flow rate from tank 241-C-103 through the existing high efficiency particulate air filter. The ratio of the low flow from the tank $(0.57$ cubic meters per minute $[20$ cubic feet per minute]) and much larger fresh air flow (22.7 cubic meters per minute [ 800 cubic feet per minute]) will dilute the chemicals of concern.

\subsection{SOIL CONTAMINATION FROM TANK LEAKS}

Interim stabilization (reducing the drainable liquids) by salt well pumping has been the preferred approach to minimize the risk of soil contamination beneath the tank due to tank leaks. Salt well pumping tank 241-C-103 using either pumping option is expected to reduce the tank liquids to within interim stabilization criteria. If the drainable liquids are not removed, and the liquids are stored until retrieval and disposal (approximately 30 years), some portion can be expected to leak to the soil beneath the tank adding to contamination. This additional leakage would add to the soil column clean up effort. The amount of leakage that might occur is not known, but it would be bounded by the total reported drainable liquids of 133,000 gallons. 


\subsection{IDENTIFICATION OF ALTERNATIVES}

Four options for managing the liquid waste in tank 241-C-103 have been proposed and studied. Three options would remove the organic solvent from the tank by pumping while the fourth is the no action option. Of the pumping options considered, one would transfer the organic solvent using existing salt well pumping equipment and procedures along with the pumpable aqueous liquids to a DST for storage; the other two would remove most of the organic solvent with a skimmer pump to a different DST or to an aboveground storage tank while a salt well pump would move the remaining pumpable liquids (mostly aqueous liquids with small amounts of organic solvent) to a DST for storage.

\subsection{OPTION 1}

Option 1, no action, would continue to store approximately 133,000 gallons of drainable liquids in tank 241-C-103 (including approximately 4,000 to 5,500 gallons of separable phase organic solvent). Daily leak detection surveillance would continue. If a leak was found, the tank would be allowed to leak, or a small amount of aqueous liquid would be pumped from the salt well to lower the liquid level hopefully below the tank leak. The maximum consequences would be an addition of 133,000 gallons of waste liquids to the soil contamination beneath the $\mathrm{C}$ Farm tanks. This option would include mitigation of the toxic vapor hazard by a vapor mixing system. The solvent fire hazard already presents acceptable risk but would be reduced further by controlling possible fire ignition sources through operating procedures.

\subsection{OPTION 2}

Option 2, the transfer and storage of organic solvent and pumpable aqueous liquids in a DST using the existing salt well pumping equipment and procedures, would transfer the pumpable liquid in tank 241-C-103 (both aqueous and organic solvent) to a DST for interim storage. The transfer would use existing interim stabilization equipment and procedures. Pumping could be performed with a jet pump or a submersible turbine pump in a salt well. The aqueous liquid would be transferred through a double contained receiver tank (DCRT) where the $\mathrm{pH}$ would be adjusted (by adding sodium hydroxide) to meet DST storage criteria and then transferred to a DST for interim storage until the waste was retrieved for pretreatment and disposal. It is not recommended that the organic solvent be processed through the 242-A Evaporator or the Effluent Treatment Facility, as the impacts on these systems are significant and include equipment fouling and premature failure, increased emissions, and downstream organic contamination.

Salt well pumping would transfer the major portion of the solvent to a DST and leave the remainder in tank 241-C-103 as puddles or permeated within the waste sludge. 
Salt well pumping is expected to reduce drainable liquid to meet interim stabilization criteria thus addressing potential contamination of the soil beneath the $\mathrm{C}$ Farm caused by tank leaks. The toxic vapor hazard would be addressed by a vapor mixing system. The solvent fire hazard would present acceptable risk but would be reduced further by controlling possible fire ignition sources through operating procedures.

\subsection{OPTION 3}

Option 3 consists of skimming, transfering and storing most of the organic solvent into a suitable DST with subsequent salt well pumping of remaining pumpable liquids to a different DST. The reason for two DSTs is to segregate the solvent whose waste cannot be processed through the 242-A Evaporator. It might be possible to send the aqueous liquid through the evaporator to reduce waste volume. The skimming process is expected to leave a layer of organic solvent, 1 to 2 millimeters thickness, in tank 241-C-103. Subsequent salt well pumping would transfer a portion of this solvent to the DST and leave the remainder in tank 241-C-103 as puddles or permeated with the waste sludge.

Salt well pumping is expected to reduce drainable liquid to meet interim stabilization criteria thus addressing potential contamination of the soil beneath the $C$ Farm tanks caused by tank leaks. The toxic vapor hazard would be addressed by a vapor mixing system. The solvent fire hazard would present acceptable risk but would be reduced further by controlling possible fire ignition sources through operating procedures.

\subsection{OPTION 4}

Option 4 consists of skimming and storing most of the organic solvent in an aboveground storage container with subsequent salt well pumping of remaining pumpable liquids to a DST. The skimmed solvent would be separated from the aqueous liquids in an aboveground coalescer unit and then transferred to an aboveground storage tank (tank on a truck). The solvent would be stored in a permitted location until treatment or offsite processing is possible. The pumpable aqueous liquids would be salt well pumped to a DST for storage and possible processing through the 242-A Evaporator and Effluent Treatment Facility. The skimming and separation process is expected to leave a layer of organic solvent from 1 to 2 millimeters thickness behind in tank 241-C-103. Subsequent salt well pumping would transfer a portion of this solvent to a DST and leave the remainder in 241-C-103 as puddles or permeated with the waste sludge.

Salt well pumping is expected to reduce drainable liquid to meet interim stabilization criteria and thus addresses potential contamination of the soil beneath the $C$ tank farm caused by tank leaks. The toxic vapor hazard would be addressed by a vapor mixing system. The solvent fire hazard would present acceptable risk but would be reduced further by controlling possible fire ignition sources through operating procedures. 


\subsection{CRITERIA AND ASSUMPTIONS}

The most important criteria in selecting a pumping option are public health and safety, worker safety, environmental compliance, engineering feasibility, and cost. A weighting factor ( 1 to 3$)$ is applied to these criteria to reflect the relative importance among them.

\subsection{PUBLIC HEALTH AND SAFETY}

This criterion addresses the risk of airborne release of toxic and radioactive material that may expose individuals onsite and offsite. The hazards that are key in selecting between the options include solvent fire accidents and waste transfer and handling accidents. Public Health and Safety impacts are very important and are assigned a weighting factor of 3.

\subsection{OCCUPATIONAL HEALTH AND SAFETY (ALARA)}

This criterion addresses the risk posed to tank farm workers, during the implementation of the option and during other waste management activities that must be performed in the vicinity of the tanks and other equipment. Worker safety is a very important consideration and is assigned a weighting factor of 3 . Worker risk is considered in the following areas:

- Radiation protection, primarily from direct exposure to contaminated equipment and pump pits and also from shine through aboveground process and storage containers

- Toxic gas exposure resulting from workers performing tank farm operations near tank openings that may be venting tank headspace gases

- Industrial safety hazards that may cause injury or illness during the construction, operation, and decommissioning of equipment involved in these options.

\subsection{ENVIRONMENTAL COMPLIANCE}

This criterion addresses the technical environmental impacts, the administrative burden of obtaining permits required under environmental compliance regulations, and finally, and perhaps most importantly, the regulatory impacts as framed within the Tri-Party Agreement commitments. Although important, the technical environmental impacts and administrative burden address chronic impacts rather than acute health effects. They are assigned a weighting factor of 2 . Environmental compliance impacts are considered in the following areas: 
- Administrative burden involved in seeking the required permits to address hazardous waste/Resource Conservation and Recovery Act, and air emissions regulations

- Environmental considerations (chronic health effects) related to contamination of the soil and ground water

- Regulatory considerations (i.e., the impact to the Tri-Party Agreement) regarding changes to baseline assumptions and milestone schedules.

\subsection{FEASIBUITY}

This criterion addresses the engineering and operational impacts involved in implementing the options including:

- Operability impacts such as the effect of each option on performing other waste management activities (e.g., retrieving the waste in tank 241-C-106, which is near tank 241-C-103 and evaporates water from the waste in the receiver DST).

- The ease or difficulty of implementing the option (e.g., the amount of technical development, engineering, and procurement required).

- The impact each option has on decontamination and decommissioning of the facility (i.e., creating new waste or making the retrieval, pretreatment, and disposal of existing waste more difficult).

Feasibility considerations address the ease or difficultly involved in each option. With proper engineering and operational implementation, all options can be done. As such, feasibility is judged to be relatively less important than safety and environmental impacts. Feasibility is assigned a weighting factor of 1.

\subsection{COST}

The cost criterion addresses: (1) near term engineering, capital, and operational costs of implementing the option, (2) life cycle costs such as those due to increased maintenance or surveillance requirements, and (3) cost impacts on long term pretreatment, disposal, and site cleanup efforts. Cost is a particularly important consideration in a tight waste management budget as the resources spent on managing the waste in tank 241-C-103 consume resources that could otherwise go to other important waste management activities. Cost is therefore assigned a weighting factor of 2 . 


\subsection{COMPARISON OF ALTERNATIVES AND SELECTION OF RECOMMENDED OPTION}

The four options are evaluated against the various criteria and are assigned a rating based on the relative benefit or detriment each option represents. The rating scale ranges -3 to +3 . A -3 rating signifies a major detriment relative to a criterion. 0 signifies that the option is neutral (neither beneficial nor detrimental); and a 3 signifies a major benefit relative to the criterion. The basis for each rating is discussed below.

\subsection{PUBLIC HEALTH AND SAFETY}

The risk posed by each option has been analyzed as part of the ongoing tank farm safety analysis and authorization basis upgrade process. The analyses focus on airborne release of radioactive and toxic material resulting from various postulated accidents associated with waste storage and waste transfer operations. These analyses were performed primarily to determine what controls, if any, are needed to maintain risk within Westinghouse Hanford Company risk acceptance guidelines (RAGs). Therefore, the analyses were performed in a conservative and deterministic manner, and they calculated consequences to maximally exposed receptors. Accident frequencies were estimated and assigned to a frequency class, also in a conservative manner. The accidents most impacted by the different pumping options are solvent fires and waste transfer accidents. These accidents have very low consequences (less than 1 millisevert) for receptors at the site boundary. These postulated accidents are plotted against the Westinghouse Hanford RAGs for onsite receptors (see Figure 5-1 for pumping options and the "no action" option. As indicated and discussed below, with implemented controls, all options can be accomplished within RAGs.

\subsubsection{Solvent Fires}

The degraded PUREX solvent contained in tank 241-C-103 poses a small risk as a result of possible solvent fires. Potential accidents involving this solvent have been analyzed for the various options in safety analyses reported in WHC-SD-WM-SARR-001, Supplement 1 (Postma et al. 1995) and WHC-SD-WM-SARR-034 (Geschke and Milliken 1995).

The solvent has a high flash point of around $118{ }^{\circ} \mathrm{C}$ and therefore does not represent a flammable gas hazard when maintained well below this temperature. Because of its high flash point, it is also difficult to initiate a pool fire on solvent pools and puddles. In addition, the consequences of solvent pool fires are low because the oxygen available in the tank headspace is limited, and tanks can vent combustion gases at a rate that maintains the tank structure within analyzed internal pressure limits. None of the pumping options considered remove all the solvent from tank 241-C-103, so the small risk posed by solvent fires will persist. Solvent fire consequences are well within RAGs for all options. Therefore, all options are assigned a rating of 0 (neutral) relative to this criterion. 
Figure 5-1. Radiological Risk to Maximumally Exposed Onsite Receptor.

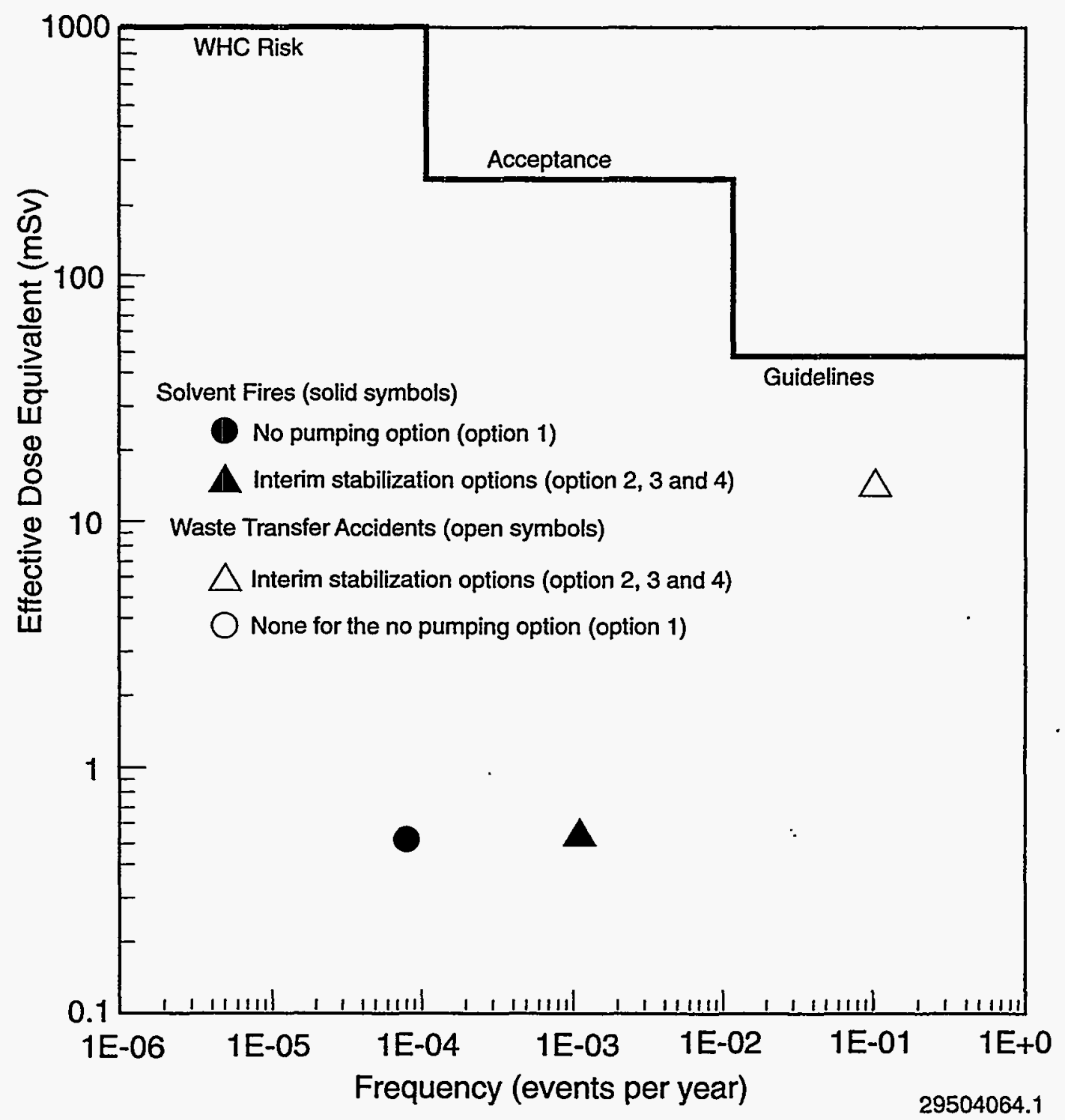

Notes:

${ }^{1}$ Risk acceptance guidelines are from the Westinghouse Hanford Company, Nonreactor Facility Safety Analysis Manual, WHC-CM-4-46, Section 7.0, "Risk," Rev. 4, March 31, 1995.

${ }^{2}$ No waste transfer accidents are possible if the waste is not pumped from the tank. 


\subsubsection{Waste Transfer Accidents}

The three options that involve salt well pumping aqueous liquids to a DST for storage present some risk from waste transfer accidents. In particular, salt well pumping of aqueous liquids can result in releases caused by transfer line breaks that cause waste pools to form on top of the ground and pressurized spray releases that can occur at leaks and cracks at piping connections (jumpers) within valve pits and diversion boxes. Such accidents, of course are not unique to the salt well pumping of tank 241-C-103, but they are more risky than solvent fires. The risk involved in transferring the drainable liquids from tank 241-C-103 to a DST are analyzed in Geschke and Milliken (1995). Unmitigated, both accidents would result in consequences to the onsite receptor above RAGs. Offsite consequences are very low (less than 1 millisevert) for all postulated accidents. With implemented operation safety requirement controls to mitigate the accident severity, the onsite consequences fall within RAGs. Because the risk is dominated by the release of aqueous liquids and entrained sludge solids and is not significantly affected by the organic solvent, all pumping options (Options 2,3 , and 4) pose similar risk and are assigned a rating of -1 (somewhat detrimental) in terms of this criterion.

\subsection{OCCUPATIONAL HEALTH AND SAFETY}

This criterion addresses the risk posed to tank farm workers, during the implementation of the option and during other waste management activities that must be performed in the vicinity of the tanks and other equipment. Worker risk is evaluated in the areas of radiation doses, toxic gas exposure resulting from workers performing tank farm operations near tank openings that may be venting tank headspace gases, and industrial safety hazards that may cause injury or illness during the construction, operation and decommissioning of equipment involved in these options.

\subsubsection{Radiation Exposure}

Workers can be expected to be exposed to radiation during operations in or near a tank pit when the cover blocks are off. Such operations are needed to install pumping and skimming equipment in tank 241-C-103. Based on experience from working in and near open pits on other tanks, radiation doses of 100 millirems can be incurred over several hours. As operations generally require several workers, exposures can add up to 0.5 to 1 man rem during open pit operations.

Option 2 would require the installation of a salt well pump in the central pump pit. Worker doses are expected to be typical for such an operation. Therefore, Option 2 is assigned a rating of 0 . Option 3 would also require the installation of a salt well pump and a skimmer pump. The skimmer pump is expected to be installed in an aboveground riser and should not 
add significantly to the open pit work required. In addition to the open pit work, Option 3 will use an overground line from the skimmer riser to the central pump pit to transfer the skimmer liquids to the underground transfer line system. The line would be shielded but some radiation exposure must be anticipated. Also, the contaminated skimmer equipment and over ground transfer line would require decontamination and disposal that would result in exposure. Therefore, Option 3 is assigned a rating of -1 . Option 4 will also require the installation of a salt well pump. Before salt well pumping, a skimmer pump assembly would be installed in an aboveground riser and an aqueous return line would be installed in the central pump pit. In addition, an aboveground coalescer aqueous/solvent separations unit and solvent storage tank would be installed and operated near the tank. The skimmer, separations and storage equipment would be designed for radiation shielding, but some additional radiation exposure can be expected to occur over the other options. The aboveground solvent/aqueous separations unit contains filters to remove solid particles that are suspended in the liquids. The filters would require change-out periodically and radiation exposure can be anticipated. If the system requires repair, additional exposure would be incurred. Option 4 would contaminate equipment including the skimmer and deployment equipment, transfer lines, the separations unit, and the storage tank and truck trailer. Additional exposure can be anticipated during decontamination and disposal of this equipment. Therefore, Option 4 is assigned a rating of -2 relative to the radiation exposure criterion. Option 1, no action, would not require any open pit work or equipment decontamination, and therefore is assigned a rating of 1 .

\subsubsection{Toxic Gas Exposures}

The concentration of vapors in tank 241-C-103 are not expected to be reduced significantly by the removal of the solvent or pumpable aqueous liquids. Ammonia is likely to be generated in the aqueous liquids. Waste sludges tend to retain significant amounts of interstitial liquid following salt well pumping so it is anticipated that a significant amount of (non-pumpable) aqueous liquid will remain after pumping. It is unlikely that the ammonia generation rates will be reduced to a point where headspace concentrations will no longer be a concern. While the majority of the solvent is expected to be removed by the pumping options, it is anticipated that the amount of remaining solvent would be sufficient to maintain the headspace at or near saturated conditions. Thus the headspace concentrations resulting from the evaporation of organic solvent are not expected to be reduced significantly. Mitigation of toxic vapors is more effectively accomplished by mixing the vapors with air and venting them from a stack. Therefore, all options are assigned a rating of 0 relative to the toxic gas exposure criterion.

\subsubsection{Industrial Safety}

This criterion evaluates the impact of each option relative to the risk posed by industrial accidents that might occur during installation and removal of equipment or during pumping operations. No option requires particularly hazardous working conditions, but Option 4 does 
involve more equipment and heavy lifting (e.g., the coalescer separations unit). It is anticipated that any option could be performed safely and Options 2 and 3 are assigned a rating of 0 . Option 4 , with its additional equipment and heavy lifting, is more detrimental in this area and is assigned a rating of -1 . Option 1 is assigned a rating of 1 .

\subsection{ENVIRONMENTAL COMPLIANCE}

Environmental compliance addresses technical environmental impacts, the regulatory administrative burden such as obtaining permits required under environmental compliance regulations and perhaps most importantly, the long term waste management and cleanup regulatory impacts as framed within the Tri-Party Agreement.

\subsubsection{Administrative Impacts}

The administrative aspects associated with evaluating potential environmental releases and obtaining the proper required permits has been evaluated for the various options. The Foster Wheeler Environmental Corporation (1995) discusses the environmental permitting aspects of Options 2 and 3 and concludes that there are no significant regulatory actions that would prevent transferring tank 241-C-103 liquids (solvent and aqueous) to a DST. Depending on final evaluation by appropriate Westinghouse Hanford environmental personnel, impacts or changes to permits or notices of construction may occur, but these are not considered significantly detrimental to these options. Therefore, the administrative regulatory impacts associated with Option 2 and 3 are assigned a rating of 0.

Environmental regulatory impacts associated with skimming the solvent to an aboveground storage tank have been evaluated in Parazin (1994). The "Notice of Construction For Organic Removal From Tank 241-C-103" has been transmitted to the Washington Department of Health and the Environmental Protection Agency. A Resource, Conservation and Recovery Act, Part A revision has been prepared to include container storage areas within C and B farms. In unit manager meetings, the Washington Department of Ecology indicated waiver of notice of intent requirements would be released from this activity thereby reducing the lead time requirements for permitting. There appears to be no significant impacts that would prevent implementation of Option 4, therefore, Option 4 is assigned a rating of 0 .

Option 1 requires no additional regulatory permitting paper work and therefore is assigned a rating of 1 .

\subsubsection{Technical Impacts}

Potential contamination of the environment is an important consideration. Contamination from airborne releases resulting from accidents can be inferred from the airborne accident 
analysis discussed in Section 5.1. The salt well pumping operations pose some risk of airborne contamination caused by transfer line breaks and spray releases. A conservative estimate of the probability of such an event occurring during the pumping of tank 241-C-103 is stated as 0.10 (Geschke and Milliken 1995). Given this probability, it is more likely that interim stabilization by salt well pumping would result in no significant airborne contamination. Not pumping the tank, however, is likely to result in waste leaks to the ground beneath the tank. The likelihood and possible health impacts of tank leaks have been studied previously in the Near Term Safety Study for Interim Stabilization of Non-Watchlist Tanks, WHC-SD-WM-RPT-044 (Kummerer et al. 1992). Based on leak histories for single-shell tanks (SSTs), it was estimated that the frequency of a specific tank to leak ranges from 0.01 per year to 0.033 per year. Because the leak frequency over $40+$ years is not uniform over time (i.e, it appears to be higher initially and lower recently), this estimate may be higher than the current leak frequency. However, if the drainable liquids are stored in tank 241-C-103 until retrieval and disposal (approximately 30 years), the probability that the tank will develop a leak approaches one.

The radiological consequences of tank leaks were estimated in the study and the conclusion was that scenarios where exposures occurred outside of the site boundary (i.e., along the Columbia River) lead to very low consequences. For scenarios that assume agricultural use of the Hanford Site in the future, failure to clean up the contaminated ground water could lead to higher consequences. The soil and groundwater beneath the 200 Area have received contamination from other tank leaks and past waste management operations, therefore, leaks from tank 241-C-103, would add to the contamination and not be the only cause for possible consequences. Because the offsite consequences of tank leaks are low and contamination beneath the 200 Area cannot be avoided only by interim stabilization of tank 241-C-103, the health impact of not salt well pumping is assigned a rating of -1 . Pumping the tank by any available option would most likely result in little or no leaks to the soil. Therefore pumping options are assigned a rating of 1 .

\subsubsection{Regulatory/Tri-Party Agreement Impacts}

The regulatory/Tri-Party Agreement impact of not interim stabilizing tank 241-C-103 appears to be major. The SST system is operated under interim status as a treatment and storage unit under Washington Administrative Code 173-303. Washington Administrative Codes require that leaking underground storage tanks be taken out of service and their contents removed to avoid further leaks. Although the SST system cannot be operated within all of the WAC requirements (due to its age and the limited design features included when the system was built), the removal of drainable liquids from the SSTs is strongly recommended to minimize contamination of soil and ground water beneath the 200 Area. The commitments to manage the waste in the SSTs are included in the Hanford Federal Facility Agreement and Consent Order (Tri-Party Agreement). The milestones represent the actions necessary to ensure acceptable progress toward compliance with Resource, Conservation and Recovery Act, the Comprehensive Environmental Response Compensation and Liability Act (CERCLA), and 
the Washington State Hazardous Waste Management Act. The Tri-Party Agreement includes the following commitments relative to interim-stabilization of tank 241-C-103 as shown in Table 5-1.

Table 5-1. TPA Milestones for Interim Stabilization of Single-Shell Tanks.

M-40-00 Complete Single-Shell Tank Interim Stabilization

Complete interim stabilization activities for all SSTs except tank 241-C-106 (to be retrieved in accordance with milestone M-45-03). Complete intrusion prevention for all SSTs except tank 241-C-106.

This is dependent upon the following assumptions:

- Safety studies will be completed with the objective of allowing pumping in accordance with interim milestones.

- Work commences in the tânk farms on October 1, 1993 for interim stabilization preparations, as required by the milestone schedules. During the stand down in tank farms, schedules for the following interim milestones may be affected: M-41-01, M-41-02, M-41-10, and M-41-16. Every effort will be made to recover the original schedule as specified below.

- Interim milestones for start of pumping and target completion for each group of tanks will be reviewed and affirmed annually with Ecology and EPA. Upon start of pumping, efforts to continue pumping will be continuously supported so that pumping is conducted as expeditiously as practical. If pumping is interrupted to a degree that jeopardizes the target milestone, the unit managers shall meet in the effort to agree on a recovery plan. If such an agreement cannot be made at the unit manager level, a formal recovery plan will be prepared and submitted to Ecology for approval supporting the major milestone date of September 2000, if technically achievable.

M-41-19 Start Interim Stabilization of 1 Organic 9/30/1998 Watch List Tank in 241-C-Tank Farm. 3/31/1999

M-41-19-T01 Complete Interim Stabilization of 1 Organic Watch List Tank in 241-C-Tank Farm. 
Because a major tenet of the Tri-Party Agreement is interim stabilization of SSTs, and because safety studies for the interim stabilization of tank 241-C-103 indicate no unacceptable risk caused by interim stabilization of this tank, Option 1 is rated as a major detrimental impact against this criterion and is assigned -3. Options 3 and 4 which could be implemented to meet the Tri-Party Agreement milestones, are assigned a rating of 2. Option 2, which might be implemented earlier than the Tri-Party Agreement milestone dates is rated as more beneficial against this factor and is assigned a rating of 3 .

\subsection{ENGINEERING FEASIBILITY}

This criterion addresses the engineering and operational impacts involved in implementing the options including operability impacts such as (1) the effect of each option on performing other waste management activities, (2) the ease or difficulty of implementing the option such as the amount of technical development, engineering, and procurement required, and (3) the impact of each option on decontamination and decommissioning of the facility.

\subsubsection{Operability}

The impact of Options 2 and 3 on tank farm equipment has been evaluated (Foster Wheeler Environmental Corporation 1995). Transferring organic solvent through the existing routes (pipes, valves, etc.) may have a detrimental effect on some organic-based parts such as jumper gaskets and pump and valve packing seals. Also, the potential exists for organic solvent transfer line leaks to drain back into catch tanks or other waste storage tanks depending on the selected transfer route. Additional waste management action may be required to address such leaks. The pumping of the liquid using current underground lines should not have a significant impact on other waste management operations that may be in progress concurrently in the C-Farm (e.g., tank 241-C-106 waste retrieval).

Transferring solvent to the DST system potentially impacts waste reduction operations using the 242-A Evaporator and the Effluent Treatment Facility because solvent should not be processed through these systems. Options 2 and 3 are expected to transfer approximately 133,000 gallons of liquids from tank $241-\mathrm{C}-103$. As the capacity of the double-contained receiver tanks is only approximately 10,000 gallons, the transfer would occur in several batches. Aqueous liquids are expected to be transferred first as the solvent is floating well above the salt well pump suction point. Several batches of aqueous liquid may be transferred to a suitable DST and subsequently processed through the evaporator, if desired. The final batches are expected to contain the bulk of the solvent. These batches may be routed to a different DST containing waste that is not scheduled to be processed through the evaporator. Option 3 would accomplish roughly the same goal by skimming the organic solvent to a suitable DST before salt well pumping. Options 2 and 3 would appear to have similar capabilities to separate and segregate the solvent from the aqueous liquid. 
In addition, preliminary analysis of tank $241-\mathrm{C}-103$ aqueous liquid indicates this waste is not a good candidate for evaporation because of relatively high concentrations of dissolved organic compounds and phosphate ion. Further evaluation, including boildown tests, is recommended. A worst case scenario is that the aqueous liquids cannot be evaporated and must be segregated to a DST containing waste that is not suitable for evaporator feed. A preliminary evaluation of this scenario indicates that such DST storage space is limited until after the turn of the century. Therefore, the impacts of Options 2 and 3 on waste reduction operations are not considered to differ significantly from Option 4, and they are assigned a rating of 0 .

The operational impact of skimming the solvent to an aboveground storage tank is discussed briefly in Parazin (1994). Only one impact is identified, that is, possible interferences with Project W-320, retrieval of waste from tank 241-C-106, which is scheduled to be working in the C Farm during the same timeframe as tank 241-C-103 organic skimming would be in operation. This possible interference can be worked around and is not considered significant. Based on available information, there appears to be no major impact on other waste management operations. Therefore, Option 4 is assigned a rating of 0 .

Option 1, no action, appears to have no operational impacts in affecting other waste management activities. It is assigned a rating of 1 .

\subsubsection{Implementation}

There is a benefit to implementing any option quickly and easily, and with little risk of unforseen difficulties. Option 2 uses existing tank farm equipment and procedures, and the process has been performed many times in the past. Some additional work is needed to assure that solvent leaks could be detected during the transfer, since the low electrical conductivity of the solvent makes it difficult to detect leaks with existing conductivity type leak detectors. Leak detection can be done, however, so Option 2 is assigned a rating of 0 .

Option 3 requires the design and procurement of skimmer pump technology and equipment. Commercially available skimmers have been tested and are expected to be able to remove all but a few millimeters of the solvent layer. Several outstanding engineering issues must be addressed before the skimmer technology can be used in tank 241-C-103. These include material compatibility, process line joint flexibility, and skimmer pump deployment. The skimmer design choice that resulted from testing is too large to be deployed in a salt well. As a result, either the skimmer must be downsized and retested, or the skimmer must be deployed through a different tank riser. Deployment equipment would need to be designed and procured. Because significant additional design and development is needed for the skimmer technology, Option 3 is assigned a rating of -1 .

Option 4 is in the advanced planning stage, and much of the long lead equipment has been procured. Several issues still need to be resolved. Option 4 requires similar skimmer development and design as Option 3. The aboveground coalescer separation unit also needs 
further design work. Because storage of the solvent onsite in an aboveground tank is a temporary solution, a viable means for treating the solvent or disposal of it offsite needs to be identified. Shipping container design and U.S. Department of Transporation Approval needs to be completed. In addition, known vendor specifications for disposal by incineration are stringent. The required feed rates to the incinerator would be low resulting in high disposal costs. Parazin (1994) provides a schedule for implementing Option 4 which indicates that this option could be implemented within 17 months of restart. Based on the amount of additional design, development and procurement needed to implement skimming, separation and aboveground storage, this option is assigned a rating of -2 .

Option 1, no action, has no implementation impacts and is therefore assigned a rating of 4.

\subsubsection{Decontamination and Decommissioning}

The impacts of each option on long-term waste management (retrieval, pretreatment, disposal) and site cleanup efforts are considered in this criterion.

All options will leave some solvent in tank 241-C-103. This solvent may impact long-term pretreatment and disposal of SST wastes, but because the long-term disposal process has not been established, this potential effect is not considered significant in selecting between the pumping options.

Options 2 and 3 would transfer approximately 5,000 gallons of solvent to the DSTs. The presence of solvent in the DST waste has some potential to impact the long-term disposal of tank wastes. The Tank Waste Remediation System flowsheet (Orme 1994) does not include processing of separable phase organics. It is recommended that separable phase organics not be processed through the currently designed waste pretreatment facility. Possible impacts include ion exchanger fouling, increased waste generation (e.g., ion exchange resin) and downstream organic contamination. There are no processes for removing and destroying separable phase organics included in the pretreatment facility design.

The impact of separable phase organics on ion exchange removal of cesium and target ions is a technology issue requiring further evaluation. It is doubtful that the layer in tank 241-C-103 is the only separable organic stored in the tank farms. A recent study of the PUREX plant material balances from 1955 to 1991 indicated that the quantity of solvent (NPH and TBP) sent to the tank farms entrained in organic wash waste may be considerable, up to 655,000 gallons (Sederberg and Reddick 1994). Much of this solvent may have been evaporated or chemically aged. However, the amount of solvent that may have escaped the waste is unknown. Organic solvents may have been transferred from SSTs to the DSTs during past interim stabilization efforts and solvent transfer from PUREX directly to the DSTs is very probable. PUREX solvent, however, is expected to undergo chemical reactions with the radioactive, alkaline DST wastes. These reactions include the saponification and radiolysis of TBP to soluble dibutyl phosphate and other organic compounds. The forced ventilation systems provided the DSTs are expected to cause significant evaporation of NPH. 
Therefore, the amount of separable organic which remains in the DSTs after many years of storage may be much reduced from the amount transferred to the tanks. Therefore, the treatment and disposal of separable phase organics require evaluation regardless of the disposition of the layer in tank 241-C-103. If separable organics are evaluated to remain in the DSTs at the time when retrieval and pretreatment begin, procedures and equipment could be developed by pretreatment to minimize potential impacts of these separable phase organics on processes for removal of cesium and target ions. Transfer of 5,000 gallons of organic solvent to the DSTs (rather than skimming to an aboveground tank) will add to the separable phase that must be processed and disposed of. Options 2 and 3 are assigned a rating of -1 .

Option 4 would avoid much of the solvent addition to the DSTs and thus result in less separable phase organic that might require processing during DST waste pretreatment and disposal. This a benefit. Option 4 would contaminate more equipment than Options 2 or 3 . This includes the skimmer pump and deployment equipment, the aboveground coalescer unit, transfer lines, aboveground storage tank and truck, and potentially the storage pad. In addition, the organic solvent will require long-term disposition. Options for onsite treatment or offsite disposal are not available so additional development of disposal options would be required. The decommissioning impacts of Option 4 are beneficial and detrimental. Although the benefits outweigh the detriments, Option 4 is assigned a rating of 1 .

Option 1, no action, would leave more solvent in tank 241-C-103 than the other options. The impact of the solvent on SST waste retrieval, pretreatment, and disposal is not known. The solvent, however, will probably need to be treated during SST pretreatment, and disposal in a manner similar to that required to process DST wastes as discussed for Options 2 and 3. Based on the additional amount of solvent left in tank 241-C-103 that may need to be treated during SST waste pretreatment and disposal, Option 1 is assigned a rating of -1 .

\subsection{COSTS}

The cost criterion addresses near-term engineering, capital, and operational costs of implementing an option; life-cycle costs such as those caused by increased maintenance or surveillance requirements; and cost impacts on long-term pretreatment, disposal, and site cleanup efforts.

Option 2 is estimated at approximately $\$ 1$ million. This is similar to the cost of pumping other SSTs. Implementation is assigned a rating of 0 . There is no significant impact on life-cycle costs expected different from interim stabilized tanks. Life-cycle costs are assigned a rating of 0 . There is a possible increase in the costs for pretreatment of the DST wastes caused by additional solvent processing. This impact is unknown but is expected to be a small incremental cost if separable phase organics are stored in the DSTs already (from previous transfers from SSTs or from transfers from PUREX directly). Disposal cost impacts are therefore assigned a rating of 0 . 
The implementation costs of Option 3 are similar to Option 2 with the addition of developing and implementing the skimmer, skimmer pump, and deployment equipment. The additional cost, which is estimated to be $\$ 500,000$, causes implementation costs to be assigned a rating of -1 . The life-cycle costs are the same as Option 2, therefore a rating of 0 is assigned. The pretreatment and disposal impacts are also the same as for Option 2, but additional equipment would need to be decontaminated and disposed of; therefore, a rating of -1 is assigned.

Option 4 involves considerable design, development, capital, and operating costs. These costs are estimated to be $\$ 8$ million. This does not include the cost to dispose of the solvent. Option 4 is assigned a rating of -2 . The aboveground storage of the solvent will require additional maintenance and surveillance of the storage tank and pad. These life-cycle costs have not been specifically estimated but are not expected to be large. These costs are in addition to maintenance and surveillance costs that are applicable to Options 2, 3; therefore Option 4 is assigned a rating of -1 .

Although Option 4 avoids much of the impact of increased solvent in the DST waste stream that must be processed through pretreatment and disposal, it incurs a cost for onsite solvent treatment or offsite disposal of the skimmed and separated solvent. Because no option is available for disposing of the solvent, costs are unknown, but could be significant. The incremental cost of treating the tank 241-C-103 solvent during DST waste pretreatment and disposal, however, is approximately equal to the cost of onsite treatment or offsite disposal of the skimmed solvent. Option 4 is assigned a rating of 0 .

Option 1, no action, avoids implementation costs and is therefore assigned a rating of 1 . However, as the drainable liquids will remain in tank 241-C-103, additional leak detection surveillance costs would be incurred. A noninterim stabilized tank requires daily surveillance using an online liquid level sensor (i.e., an Enraf liquid level detector) while an interim-stabilized tank requires only weekly surveillance, generally using a liquid observation well scanning technique. Daily leak detection surveillance is more expensive than weekly surveillance and over many years (about 30 years until SST waste disposal) can amount to a significant cost penalty for this option. Life-cycle costs for Option 1 are therefore assigned a rating of -1 .

The cost impact of additional tank leaks on soil cleanup, which has not been estimated, should be considered an incremental cost since the soil is already contaminated because of leaks from other tanks and past waste management operations. Although incremental cleanup costs have not been estimated, they could be significant. Therefore, Option 1 is assigned a rating of -2 . 


\subsection{RESULTS}

The results of the evaluation are shown in Table 1-1. The ratings for each criterion are averaged, then multiplied by a weighting factor to give a rating result for each option. The results are summed for all criteria to produce a total rating for each option.

Table 1-1 shows that Option 2, transferring and storing the organic solvent and pumpable aqueous liquids to a DST(s) using existing salt well pumping equipment and procedures of the options considered rated highest. Option 3, skimming the solvent to a DST before salt well pumping had similar ratings to Option 2 , but it required additional costs and implementation issues with no real benefits. Option 4, skimming the solvent to an aboveground storage tank does not substantially improve safety or environmental impacts, but it does have potential benefits relative to waste pretreatment and disposal efforts. There are no processes for removing and destroying separable phase organics included in the pretreatment facility design. It is questionable that the layer in tank 241-C-103 is the only separable organic stored in the tank farms. Therefore, the treatment and disposal of separable phase organics will require evaluation regardless of the disposition of the layer in tank 241-C-103. Procedures and equipment could be developed by pretreatment to minimize potential impacts of separable phase organics on processes for removing cesium and target ions. The processing of the solvent, in tank 241-C-103 through a revised pretreatment system is determined to be an incremental impact as other separable phase organics are likely to require processing anyway. Option 4 does involve substantial cost and implementation penalties, therefore rates lowest of the options. The no action option has significant benefits in cost and implementation and minor benefits in public and worker safety, but it involves major Tri-Party Agreement/regulatory penalties. For these reasons, Option 1 has the second highest rating. 
WHC-EP-0862

This page intentionally left blank. 


\subsection{REFERENCES}

Ecology, EPA, and DOE, 1994, Hanford Federal Facility Agreement and Consent Order, as amended, Washington State Department of Ecology, U. S. Environmental Protection Agency, and U. S. Department of Energy, Olympia, Washington.

Foster Wheeler Environmental Corporation and Science Applications International Corporation, 1995, Requirements and Actions for Pumping the Tank 241-C-103 Organic Layer to a Double-Shell Tank, Foster Wheeler Environmental Corporation, Richland, Washington.

Geschke, G. R., and N. J. Milliken, 1995, Safety Evaluation for the Interim Stabilization of Tank 241-C-103, WHC-SD-WM-SARR-034, Rev. 0, Westinghouse Hanford Company, Richland, Washington.

Grigsby, J. M., J. E. Meacham, M. G. Plys, A. K. Postma, D. A. Turner, and J. C. Van Keuren, 1995, Risk from Organic Solvent Fires in C-103 Following Interim Stabilization, WHC-SD-WM-SARR-001, Supplement 1, Westinghouse Hanford Company, Richland, Washington.

Kummerer, M., S. D. Estey, M. G. Piepko, and G. L. Powers, 1992, Near Term Safety Study of Interim Stabilization of Non-Watch List Tanks, WHC-SD-WM-RPT-044, Rev. 0, Westinghouse Hanford Company, Richland, Washington.

Orme, R. M., 1994, TWRS Process Flowsheet, WHC-SD-WM-TI-663, Rev. 0, Westinghouse Hanford Company, Richland, Washington.

Parazin, 1994, Removal of Floating Organic in Hanford Waste Tank 241-C-103 Restart Plan, WHC-SD-WM-PLN-092, Rev. 0, Westinghouse Hanford Company, Richland, Washington.

Sederberg, J. P., and J. A. Reddick, TBP and Diluent Mass Balances in the PUREX Plant at Hanford 1955-1991, WHC-MR-0483, Rev. 0, Westinghouse Hanford Company, Richland, Washington.

WHC-CM-4-46, Nonreactor Facility Safety Analysis Manual, Westinghouse Hanford Company, Richland, Washington. 


\section{DISTRIBUTION}

\section{Number of Copies}

ONSITE

7

U.S. Department of Energy

Richland Operations Office

M. F. Jarvis

S7-54

S. O. Branch (5)

S7-54

S. T. Murff (MACTEC)

S7-73

20

Westinghouse Hanford Company

R. A. Dodd

S5-05

D. J. Washenfelder

H5-27

G. T. Dukelow (3)

S7-15

D. A. Turner (3)

S5-07

D. B. Engelman

R1-49

G. L. Dunford

S7-81

J. M. Grigsby

S7-15

E. J. Lipke

S7-14

T. E. Rainey

R2-54

N. W. Kirch

R2-11

L. D. Arnold

B2-35

Central Files

L8-04

OSTI (2)

L8-07

TFIC

R1-28 